\title{
WORK HISTORY OF NURSES TRAINED IN NATAL.
}

\author{
Leana R. Uys
}

In a recent survey it was found that although Nata!/KwaZulu has $25.1 \%$ of the South African population, it has only $20,9 \%$ of the country's registered nurses (Muller and Coetzee, 1990). This means that Natal has the worst population to registered nurse ratio of the three large urban areas (Natal 551:1, Western Cape 324:1; Pretoria/Witwatersrand 319:1). The same report showed that, although, Natal/KwaZulu has $25,1 \%$ of the population, it only trains $9,2 \%$ of the current nursing students (Ibid). These figures paint a worrying picture of the region's ability to supply the health manpower needs of its people.

Over the last three years the posts for degree students in Natal have been cut by $43 \%$, ie from $\mathbf{7 0}$ posts to $\mathbf{4 0}$ for the four years. The verbal reasons given to the Department of Nursing, University of Natal for this cut, over and above the lack of funds, was that degree nurses do not give as much service to the Provincial Administration as do nursing diploma students.

In a recent study comparing the service rendered by these two groups who completed their training in the Free State, it was found that diplomates have worked $69 \%$ of the years since they completed training, as compared to the $60 \%$ of the graduates (Uys 1988). It was found, however, that diplomates tended to work for private hospitals and in the consulting rooms of physicians to a greater degree than graduates.

In studies done in the United Kingdom it was found that, contrary to general expectations, between 68 and $80 \%$ graduate nurses usually stay in nursing (Bircumshaw and Chapman 1988; Kamp, 1988). It was also found that most of them start off in hospital nursing, and though some move to the community services or educational institutions over time, the majority stay in hospitals. After a follow-up study completed on the graduates of the University of Ulster a news report from the London Times stated that these nursing graduates showed a marked preference for clinically-orientated posts; this finding was contrary to the expectation that the graduates would be over-represented in education and administration (Times Higher Education Supplement 1987).

A study from the University of Natal which investigated the working lives of the 139 nursing graduates produced during the years
1962-77, found that $90,6 \%$ of the group's working years had been spent within nursing (Hunt 1981) but this study does not indicate where this service was rendered. There are also no data on the working lives of diplomates from the Natal training schools with which graduates could be compared

It was decided therefore to do a survey of diplomates and graduates from Natal training schools in order to establish answers to the following questions:-

1. In which regions, types of work, positions and for which employers did diplomates and graduates work?

2. How much of the time available after training did they spend in nursing?

3. How many of them furthered their education after nursing training and which courses did they take?

\section{METHODOLOGY}

The survey was carried out by means of a mailed questionnaire, the same as that used in an earlier study (Uys 1988). Questions were asked about the training school, the date of completion of training and further studies. Respondents were then asked to fill in details about all jobs they have had in nursing, stipulating the duration, area of the country, employer, type of work and position held.

Sampiing was problematic since a complete sampling frame of diplomates was not available, and in the case of graduates current addresses were often impossible to find. It was decided to include only White diploma training schools in the survey, to make this group more comparable to the graduate group.

The following strategies were followed to trace as many diplomates as possible.

- Diploma training schools were contracted and lists of alumni and their addresses obtained where possible

- Every questionnaire sent out was accompanied by a letter asking the respondent for the addresses of othet nurses from the same training school. In this way snowball sampling was used.
- A printout of addresses of diplomates who completed training from 1985 to 1987 was obtained from the SA Nursing Council.

- Questionnaires were taken to the Durban hospitals employing mostly White nurses. and nurse managers were asked to distribute these

In these ways about 1000 addresses $w$ obtained and questionnaires sent out, of which only 38 were not delivered.

In the case of the University, a complete list of graduates was available, but current addresses could only be found for 166 of them. Even so, 12 questionnaires were retumed undelivered.

\section{RESULTS}

\section{Sample description:}

Through the distribution of questionnaires at hospitals some other-than-white diplomates responded, and it was decided not to exclude them, since due to the increasing integration of the services their pattern of employment is beginning to correspond more closely to that of White nurses. Furthermore it was felt that their inclusion adds to the significance of the study.

TABLE 1

TRAINING SCHOOL ORIGIN OF NURSES $(\mathbf{N}=\mathbf{5 2 8})$

\begin{tabular}{|c|c|c|}
\hline Training School & 1 & $x$ \\
\hline Addington & 139 & 20 \\
\hline Grope & 89 & 17 \\
\hline Si Alquetine & 27 & 5 \\
\hline Entebeni & 21 & 4 \\
\hline King Edward & 22 & 5 \\
\hline Northoles & 8 & 1 \\
\hline AK Khen & 87 & 13 \\
\hline Mocord & 28 & 5 \\
\hline Other & 48 & 9 \\
\hline DIPLOMATE TOTAL & 449 & 85 \\
\hline Unveresey of Netes & 78 & 15 \\
\hline $\begin{array}{l}\text { TOTAL nurem (diploma a } \\
\text { degree) }\end{array}$ & 528 & 100 \\
\hline
\end{tabular}

From Table 1 it is clear that Addington diplomates make up the largest single group. 
The sample realization is only about $50 \%$ of the questionnaires sent out to diplomates. This is a very small portion of the total population, since it is estimated that about 2000 White students completed their training in Natal during the last 10 years. Since the snowball technique favours the inclusion of nurses who are working, this group might be over-represented in the diplomate group. The sample in this study has therefore to be seen as a major limitation.

The nursing degree course at the University of Natal commenced in 1962 and as far as these graduates are concerned, 224 nurses had graduated by the end of 1988 , so that the 79 who responded represents a $35 \%$ sample of the total population.

TABLE 2

YEARS SINCE COMPLETION OF NURSE TRAINING

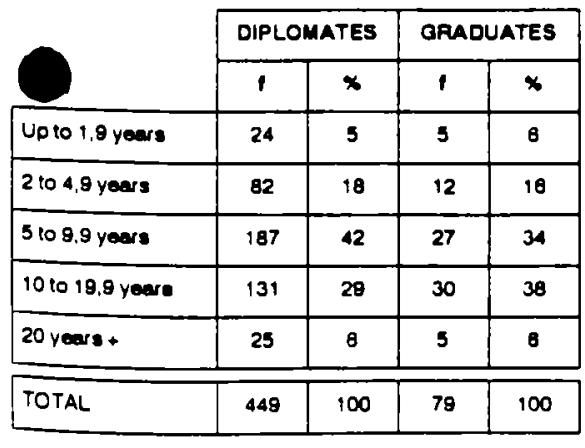

Comparing the rwo groups in terms of the years since completion of training, they seem very similar, with the majority having trained more than five but under 20 years ago.

\section{Years spent in nursing:}

The percentages of the available years after their training which these nurses actually spent in ny.jing, are reflected in Table 3.

TABLE 3

PERCENTAge Of AVAILABLE YeARS SPENT IN NURSING

\begin{tabular}{|c|c|c|c|c|}
\hline & \multicolumn{2}{|c|}{ DIPLOMATES } & \multicolumn{2}{|c|}{ ORADUATES } \\
\hline & 1 & $x$ & 1 & $x$ \\
\hline Up to $24,9 x$ & 18 & 4 & 5 & 6 \\
\hline $251049.9 \%$ & 30 & 7 & 12 & 15 \\
\hline 50 to $74,9 x$ & 56 & 13 & 18 & 23 \\
\hline 75 to $89,9 \%$ & 64 & 15 & 17 & 22 \\
\hline $90 \%$ and above & 272 & 62 & 28 & 33 \\
\hline Masung canes & 9 & & 1 & \\
\hline TOTAL & 449 & & 79 & \\
\hline
\end{tabular}

Most nurses seem to spend at least $50 \%$ of the available time in nursing. This is a significant finding in the light of the fact that most nurses are also wives and mothers. The 1989 survey of the SA Nursing Association shows that $64 \%$ of registered nurses are married or divorced and $73 \%$ are mothers (SANA 1989).
The high percentage of diplomates who spend more than $90 \%$ of the available time in nursing is remarkable. This is even more so since 249 of them (57\%) spent $100 \%$ of the time in nursing.

The percentages of both groups are higher than those of the comparable Orange Free State groups. For the OFS diplomates the average was $69.2 \%$, while it is $86 \%$ for Natal diplomates; and for OFS graduates the average was $60 \%$, while it was $72 \%$ for the Natal graduates.

\section{Further studies:}

In the interpretation of Table 4 it is important to remember that midwifery became part of the degree early in its existence, so that few graduates needed to do this separately.

TABLE 4

FURTHER STUDIES UNDERTAKEN BY THE NUASES

\begin{tabular}{|c|c|c|c|c|}
\hline & \multicolumn{2}{|c|}{$\begin{array}{c}\text { Ne4077 } \\
\text { DIPLOMATES }\end{array}$} & \multicolumn{2}{|c|}{$\begin{array}{c}\text { N-70 } \\
\text { ORADUATES }\end{array}$} \\
\hline & 1 & $\mid \begin{array}{c}x \text { of } \\
\text { caseo }\end{array}$ & 1 & $x$ of \\
\hline Miowitery & 380 & 93 & 10 & 28 \\
\hline $\begin{array}{l}\text { Community of hoevth } \\
\text { nursing }\end{array}$ & 41 & 10 & 30 & 48 \\
\hline Psychiestic nursing & 37 & 14 & 8 & 13 \\
\hline Intenaive care nursung & 29 & 7 & 8 & 13 \\
\hline Theotre technique & 33 & 8 & 3 & 3 \\
\hline Orthopeadic nurang & 6 & 2 & 12 & 19 \\
\hline Pacdiatric nursing & $\theta$ & 2 & 5 & 8 \\
\hline Nurzing oduawion & 19 & 4 & 14 & 23 \\
\hline Nureing administedon & 7 & 2 & 4 & 7 \\
\hline$B$ Depres in murving & 33 & 8 & 10 & 18 \\
\hline$M$ Depres in nuretho & 1 & 0,2 & 5 & 8 \\
\hline D Dapres in nureng & 1 & 0.2 & 1 & 2 \\
\hline 8 Doprea non-nursing & 8 & 2 & 4 & 7 \\
\hline M Oegree non-nuraing & 1 & 0,2 & 4 & 7 \\
\hline $\begin{array}{l}\text { TOTAL COURSES } \\
\text { TAKEN }\end{array}$ & 822 & & 124 & \\
\hline Mlaving coom & 42 & & 17 & \\
\hline
\end{tabular}

If midwifery is left out of the calculations, the graduate nurses seem to study more than the diplomates.

\section{Employment according to region:}

The most striking difference between the two groups with regard to the regions in which they tend to work, is that diplomates tend to be less migratory, with graduates spending more time in the Transvaal and "other" places - this often refers to time spent overseas. When interpreting this finding, it must be kept in mind that the frequencies refer to the number of jobs a person had in a specific region, and not to the total amount of time spent in that region.
TABLE 5

EMPLOYMENT ACCORDING TO REGION

\begin{tabular}{|c|c|c|c|c|}
\hline & \multicolumn{2}{|c|}{ DIPLOMATES } & \multicolumn{2}{|c|}{ ORADUATES } \\
\hline & 1 & $\begin{array}{c}\text { x of } \\
\text { romponaen }\end{array}$ & i & xoponees \\
\hline Never & 790 & 60 & 152 & 48 \\
\hline OFS & 14 & 1 & 2 & 1 \\
\hline $\operatorname{Cos}$ & 140 & 11 & 28 & 9 \\
\hline Tremovaed & 180 & 15 & 87 & 27 \\
\hline Independent statea & 17 & 1 & 2 & 1 \\
\hline Other & 47 & 4 & 49 & 13 \\
\hline Mlesing cones & 10 & & 1 & \\
\hline
\end{tabular}

Table 5 also shows that for both groups, about $57 \%$ of their nursing positions have been in Natal. This compares favourably with the OFS study, in which that province kept its nurses in only $48 \%$ of cases (Uys 1988).

\section{Employers:}

The partern of employers for diplomates and graduates as reflected in Table 6 are very similar. The main difference is that more graduates than diplomates work for the Universities. This may be the case because the nursing education sphere of the diplomate - the nursing college - falls under the provincial administration and therefore does not show up as a separate entity.

TABLE 6

EMPLOYING AUTHORTIES ASSOCLATED WITH JOBS HELD

\begin{tabular}{|c|c|c|c|c|}
\hline & \multicolumn{2}{|c|}{ DIPLOMATES } & \multicolumn{2}{|c|}{ GRADUATES } \\
\hline & 1 & \begin{tabular}{|c|} 
\% of \\
reapenaes
\end{tabular} & 1 & $\begin{array}{c}x \text { of } \\
\text { remponewe }\end{array}$ \\
\hline Unweresty & 9 & 1 & 28 & 36 \\
\hline Provincid Admin. & 600 & 49 & 128 & 40 \\
\hline Stow Hoavin & 80 & 7 & 20 & $\theta$ \\
\hline Locel Authority & 27 & 2 & 8 & 3 \\
\hline $\begin{array}{l}\text { Weffere } \\
\text { Orgerizerion }\end{array}$ & $\boldsymbol{\theta}$ & 1 & 9 & 3 \\
\hline Privano Sactor & 181 & 15 & 33 & 10 \\
\hline Nursing Services & $\pi$ & $\mathbf{\theta}$ & 18 & 5 \\
\hline Set employed & 8 & 1 & o & 2 \\
\hline Other & 217 & 18 & 89 & 22 \\
\hline Miseing caneses & 9 & & 1 & \\
\hline
\end{tabular}

\section{Type of work:}

This question was very poorly answered. The respondents experienced difficulty in keeping within the given catogories, and marked the "other" category even when the jobs clearly fell within the given categories. This might indicate pride in specialist areas, as well as differences in terminology. However, the present research cannot substantiate these conceptions. 
For both groups general hospitals in cities are the major employers. Graduates seem to move more into community and lecturing. The only significant difference between them and the diplomates seems to be their greater concentration in education fields.

TABLE 7

TYPE OF WORK UNDERTAKEN BY NURSES

\begin{tabular}{|c|c|c|c|c|}
\hline & \multicolumn{2}{|c|}{ DIPLOMATES } & \multicolumn{2}{|c|}{ GRADUATES } \\
\hline & 1 & $\begin{array}{c}\text { * of } \\
\text { reaponaces }\end{array}$ & 1 & $\begin{array}{c}\text { Xof } \\
\text { reaponnees }\end{array}$ \\
\hline City gener ai holpital & 773 & 55 & 158 & 50 \\
\hline $\begin{array}{l}\text { Rurel generd } \\
\text { hospital }\end{array}$ & 68 & 5 & 14 & 4 \\
\hline Psychietric howorta & 47 & 3 & 12 & 4 \\
\hline Clinic/day houpled & 67 & 5 & 24 & 8 \\
\hline Old age nome & 30 & 2 & 8 & 3 \\
\hline School nurso & $\theta$ & 0 & - & - \\
\hline : & 28 & 2 & 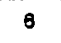 & 2 \\
\hline Lecturer & 18 & 1 & 37 & 12 \\
\hline Doctore' rooms & 39 & 3 & B & 3 \\
\hline Other & 372 & 27 & 32 & 18 \\
\hline
\end{tabular}

\section{Positions held:}

From Table 8 it is clear that most nurses spend the majority of their career, if not all of it, on the lowest step of the career ladder, ie that of professional nurse. This is specifically significant if the $100 \%$ work record of $57 \%$ of the diplomates is borne in mind.
TABLE 8

POSITIONS HELD

\begin{tabular}{|c|c|c|c|c|}
\hline & \multicolumn{2}{|c|}{ DIPLOMATES } & \multicolumn{2}{|c|}{ GRADUATES } \\
\hline & 1 & of of & f & $\begin{array}{l}\text { Xof of } \\
\text { jobs }\end{array}$ \\
\hline Protecesionel nurse & 991 & 82 & 247 & 77 \\
\hline Servior prod. nursemter & 70 & $\theta$ & 18 & 8 \\
\hline $\begin{array}{l}\text { Chivet prot. nursedemior } \\
\text { turer }\end{array}$ & $\theta$ & 1 & 13 & 4 \\
\hline $\begin{array}{l}\text { Nurs son.maneoger/ } \\
\text { principed }\end{array}$ & e & 1 & 3 & 1 \\
\hline $\begin{array}{l}\text { Chief nurasenv. maneogr } \\
\text { and higher }\end{array}$ & 3 & 0 & 1 & 0 \\
\hline Other & 132 & 11 & 38 & 12 \\
\hline Miseng cancer & 13 & & 1 & \\
\hline
\end{tabular}

\section{CONCLUSIONS}

Although one has to interpret the findings with caution because of the sample's limitations, it seems as if majority of the nurses in Natal do the work they were trained to do for a remarkable proportion of the available time. In the light of the low numbers of registered nurses being trained in Natal, this is heartening.

Although there are differences between the diplomates and the graduates, these differences do not consistently favour either group, and the similarities probably out-weigh the differences.

In comparison with the OFS group, Natal nurses seem to work more, and stay more in the region in which they were trained. The graduate group also shows the work patterns similar to these of graduates in Unired Kindgdom studies, with the majority spending most of their time in clinical settings.

\section{REFERENCES}

BIRCUMSHAW D AND CHAPMAN C M, (1988). A follow-up of the graduates of the Cardiff Bachelor of Nursing degree course. Journal of Advanced Nursing, 13 (2): 273-279.

HUNT BN, (1981). The working life of a group of nurses. Curationis, 4(2): 55-56.

KEMP J, (1988). Graduates in nursing: a report of a longitudinal study at the University of Hull. Journal of Advanced Nursing, 13 (2): 281-287.

MULLER M E AND COETZEE L, (1990). Report on the inquiry into the nursing profession 1990. Pretoria: SANA

SA NURSING ASSOCIATION, (1984). Report on the Nursing service and nursing Education in the RSA, $1979-1983$. Pretoria, SANA.

SA NURSING ASSOCLATION, (1988). average cost of basic nursing education. Pretoria, SANA (Unpublished)

SA NURSING ASSOCIATION, (1989). Nursing Kaleidoscop RSA 1984-87.

The Times Higher Education Supplement, 25.9. 1987.

UYS L R, (1988). Die werksgeskiedenis van oudstudente van die Departement Verpleegkunde, UOVS. Curationis. 11 (3): 17-19.

\section{$L R$ Uys, D.Soc.Sc. (Nursing Science) (U.O.V.S.)}

University of Natal, Durban

Professor, Department of Nursing 